DOI: $10.15193 /$ zntj/2021/126/366

\author{
MONIKA AKIMOWICZ, BARBARA SOKOŁOWSKA
}

\title{
ZAMRAŻANIE I LIOFILIZACJA JAKO TECHNIKI UTRWALANIA I PRZECHOWYWANIA MIKROORGANIZMÓW
}

\begin{abstract}
Streszczenie
Zadaniem kolekcji kultur jest gromadzenie i przechowywanie mikroorganizmów w celu ochrony bioróżnorodności zasobów biologicznych. Działają one jako repozytoria szczepów do badań naukowych, dydaktyki, zastosowań przemysłowych oraz depozytów patentowych. W kolekcjach kultur mikroorganizmów prowadzi się także badania mające na celu identyfikację, charakterystykę i klasyfikację oraz poprawę właściwości użytkowych przechowywanych zasobów. Podczas przechowywania ważne jest zachowanie w stanie niezmienionym morfologii, aktywności enzymatycznej i materiału genetycznego mikroorganizmów, jak również zapewnienie ich wysokiej przeżywalności. Zgodnie z zaleceniami Światowej Federacji Kolekcji Kultur (WFCC, World Federation for Culture Collection) ze względów bezpieczeństwa i w celu zminimalizowania ryzyka utraty szczepów powinny być one przechowywane przy użyciu co najmniej dwóch różnych procedur.

W niniejszej pracy przedstawiono zamrażanie i liofilizację jako techniki utrwalania i przechowywania mikroorganizmów najczęściej stosowane w kolekcjach. Opracowanie może być pomocne w doborze odpowiedniej techniki utrwalania, warunków prowadzenia procesu i przechowywania oraz ożywiania utrwalonych mikroorganizmów.
\end{abstract}

Słowa kluczowe: techniki utrwalania i przechowywania mikroorganizmów, zamrażanie, liofilizacja, krioprotektanty

\section{Wprowadzenie}

Organizmy żywe, ich komórki lub replikowalne części (plazmidy, genomy, cDNA) stanowią materiał biologiczny, który znajduje przemysłowe zastosowanie w wielu branżach: farmaceutycznej, rolno-spożywczej, medycznej i ochronie środowiska $[27,30]$. Kolekcje kultur mikroorganizmów, nazywane obecnie centrami zasobów biologicznych, gromadzą informacje o ich genotypach i cechach fenotypowych. Pozwalają porównywać przeszłe i obecne zróżnicowanie populacji mikroorganizmów,

Mgr inż. M. Akimowicz, dr hab. inż. B. Sokotowska, prof. IBPRS, Zakład Mikrobiologii, Instytut Biotechnologii Przemystu Rolno-Spożywczego im. prof. Wactawa Dąbrowskiego - Państwowy Instytut Badawczy, ul. Rakowiecka 36,02-532 Warszawa.Kontakt: monika.akimowicz@ibprs.pl 
przewidywać przyszłe zmiany, a także ułatwiać identyfikację pojawiających się nowych mikroorganizmów [38].

Skuteczne przechowywanie oznacza, że mikroorganizm jest utrzymywany w stanie wolnym od zanieczyszczeń, jego materiał genetyczny nie ulega modyfikacjom, nie następują zmiany jego cech fizjologicznych i morfologicznych, a po ożywieniu jest zdolny do wzrostu i namnażania w odpowiednim podłożu hodowlanym [9, 24, 34]. Na rys. 1. przedstawiono ogólny schemat postępowania z mikroorganizmami w kolekcjach kultur.

Hodowla szczepów mikroorganizmów na/w podłożu wzrostowym Cultivation of microbial strains on/in the growth medium

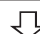

Sprawdzenie czystości szczepów poprzez prowadzenie obserwacji mikroskopowych oraz hodowlanych / Control of strain purity by conducting microscopic and culture observations

飞

Zawieszenie mikroorganizmów w medium z dodatkiem substancji ochronnych Suspension of microorganisms in medium with protective substances added

几

Utrwalenie mikroorganizmów za pomocą jednej lub kilku metod

Preservation of microorganisms by means of one or more methods

¿

Przechowywanie w odpowiednich warunkach Storage under appropriate conditions

(3)

Ożywienie mikroorganizmów (rozmrażanie, nawadnianie) Revival of microorganisms (thawing, rehydration)

○

Hodowla szczepów mikroorganizmów na/w podłożu wzrostowym Cultivation of microbial strains on/in the growth medium

\begin{tabular}{|c|}
\hline Ocena żywotności szczepów \\
Evaluation of the viability of strains
\end{tabular}

Sprawdzenie czystości szczepów poprzez prowadzenie obserwacji mikroskopowych oraz hodowlanych / Control of strain purity by conducting microscopic and culture observations

凸

Kontrola stabilności genotypowej i fenotypowej mikroorganizmów

Control of genotypic and phenotypic stability of microorganisms

Rys. 1. Ogólny schemat postępowania z mikroorganizmami w kolekcjach kultur

Fig. 1. General scheme for dealing with microorganisms in culture collections 
Najczęściej stosowanymi technikami utrwalania mikroorganizmów w kolekcjach kultur są zamrażanie i liofilizacja [2, 3, 4, 16, 27]. Wybór pomiędzy tymi technikami zależy od posiadanego wyposażenia, od rodzaju mikroorganizmów, celu utrwalania i przewidywanego czasu przechowywania.

Zgodnie z zaleceniami Światowej Federacji Kolekcji Kultur (WFCC, World Federation for Culture Collection) ze względów bezpieczeństwa i w celu zminimalizowania ryzyka utraty szczepów powinny być one przechowywane przy użyciu co najmniej dwóch różnych procedur, przy czym jedna z kultur powinna być zliofilizowana lub przechowywana w ciekłym azocie [21].

Celem artykułu było opisanie podstawowych cech oraz warunków stosowania technik najczęściej wykorzystywanych do utrwalania i przechowywania mikroorganizmów w kolekcjach.

\section{Zamrażanie (krioprezerwacja)}

Polega ona na utrwalaniu materiału biologicznego poprzez jego zamrożenie w szerokim zakresie ujemnych temperatur. Przyjmuje się, że do długotrwałego przechowywania (powyżej 5 lat) właściwa jest temperatura ciekłego azotu $-196{ }^{\circ} \mathrm{C}$ lub jego par wynosząca pomiędzy $-135 \div-150^{\circ} \mathrm{C}$, ponieważ $\mathrm{w}$ tej temperaturze nie zachodzą praktycznie żadne mutacje materiału genetycznego [2, 3, 4, 16, 19, 27]. Metoda ta jest uniwersalna i może być stosowana do każdego rodzaju materiału biologicznego. Przechowywanie w zamrażarkach (w temp. $-20 \div-80^{\circ} \mathrm{C}$ ) nie gwarantuje długoterminowego skutecznego przechowywania, nawet jeżeli początkowo daje dobre efekty [16], jest więc odpowiednie do przechowywania mikroorganizmów poniżej 5 lat oraz do przechowywania kultur roboczych. Zamrażanie materiału biologicznego jest także pierwszym etapem procesu liofilizacji (suszenia sublimacyjnego).

Zarówno podczas zamrażania, jak i liofilizacji komórki są poddawane działaniu niskich temperatur, co powoduje tworzenie kryształów w medium i wewnątrz komórek. Podczas powolnego zamrażania początkowo formują się kryształy lodu na zewnątrz komórek. Dochodzi wówczas do zaburzenia równowagi osmotycznej, odwodnienia (woda na zasadzie osmozy wypływa z komórki do otaczającego ją roztworu hipertonicznego), w efekcie czego następuje zatężanie substancji rozpuszczonych w cytozolu i skurczenie komórek (zjawisko plazmolizy) [22]. Z kolei szybkie zamrażanie komórek minimalizuje efekt zachwiania równowagi osmotycznej, ale prowadzi do tworzenia większej ilości kryształów lodu wewnątrz komórek, co powoduje ich uszkodzenie, a nawet śmierć [23, 29]. Zamrażanie może być przyczyną szeregu niekorzystnych następstw, m.in. utraty żywotności, uszkodzenia błony i ściany komórkowej, zahamowania oddychania, zatrzymania transportu aktywnego, blokowania syntezy RNA, DNA, białek, hamowania indukcji operonów oraz złożonych reakcji enzymatycznych, uszkodzenia DNA czy zmian morfologicznych komórek [7]. Uszkodzenia 
lipidów błon biologicznych, rybosomów i DNA są odwracalne, w przeciwieństwie do tych powstałych w białkach [36]. W celu zminimalizowania negatywnych skutków formowania kryształów lodu i zaburzenia równowagi osmotycznej stosuje się krioprotektanty powodujące zmianę właściwości płynu komórkowego oraz prowadzi się kontrolę tempa procesu mrożenia $[16,23]$.

\section{Krioprotektanty}

Krioprotektanty dodaje się do pożywki hodowlanej podczas wzrostu mikroorganizmów lub do zawiesiny komórek bezpośrednio przed zamrożeniem [10, 14]. Tradycyjny podział krioprotektantów uwzględnia szybkość ich wnikania do komórki. Wśród środków ochronnych szybko przenikających do wnętrza komórki, w ciągu 30 min, wyróżnia się m.in. glikol etylenowy, glikol propylenowy, dimetylosulfotlenek (DMSO) w stężeniach $5 \div 10 \%$. Wolnym tempem przenikania charakteryzują się: glicerol, mono-, oligo- i polisacharydy, sorbitol, mannitol, dekstran, glikol polietylenowy (PEG) oraz hydroksyetyloskrobia, działające krioprotekcyjnie w stężeniach $10 \div$ 40 \%. Część środków ochronnych, np. DMSO i glicerol penetruje zarówno przez ścianę, jak i błonę komórkową. Z kolei inne przechodzą tylko przez ścianę komórkową, jak mono- i disacharydy oraz aminokwasy, natomiast pozostała grupa krioprotektantów nie ma zdolności przenikania przez ścianę komórkową, jak polisacharydy czy PEG-6000 $[10,17]$.

Uważa się, że najsilniejsze działanie ochronne wykazują hydrofilowe substancje wnikające do wnętrza komórki. Takie krioprotektanty sprawiają, że błona biologiczna staje się bardziej plastyczna. Wiążą się z wodą wewnątrz komórki, chroniąc ją przed nadmiernym odwodnieniem, obniżają toksyczność metabolitów i temperaturę zamarzania wody, co zapobiega tworzeniu dużych kryształów lodu w komórce. Krioprotektanty mające zdolność przechodzenia tylko przez ścianę komórkową jedynie częściowo zabezpieczają komórkę przed odwodnieniem podczas zamrażania. Gromadzą się pomiędzy ścianą i błoną komórkową, chroniąc mechanicznie błonę biologiczną. Niepenetrujące krioprotektanty ulegają adsorpcji na powierzchni komórek. Tworzą tam lepką warstwę częściowo hamującą wypływ wody z komórki. Zwiększają lepkość roztworu na zewnątrz komórki, co spowalnia wzrost kryształów lodu. Utrzymują strukturę lodu w stanie bezpostaciowym blisko powierzchni komórki [17].

Idealny krioprotektant powinien być niereaktywny, dobrze rozpuszczalny w wodzie, mieć zdolność penetracji do wnętrza komórki, charakteryzować się niską toksycznością i nie wytrącać się przy wyższych stężeniach [27]. Substancjami ochronnymi w kolekcjach, najczęściej stosowanymi w krioprezerwacji mikroorganizmów, są glicerol $(10 \div 15 \%)$ oraz DMSO $(5 \div 10 \%)$ [2, 3, 5, 6, 35]. Glicerol wykazuje słabsze działanie niż DMSO, który jednak w wyższych stężeniach jest toksyczny dla komórek $[17,27]$. Krioprotektantem chętnie używanym w laboratoriach naukowych jest od- 
tłuszczone mleko, które z powodzeniem stosuje się przy zamrażaniu w $-80{ }^{\circ} \mathrm{C}[38,39]$. Wyniki wielu badań $[1,8,18,25,26,32,33]$ wskazują, że dla różnych grup mikroorganizmów, a często nawet dla każdego gatunku, powinno się indywidualnie dobierać odpowiedni krioprotektant.

\section{Szybkość chłodzenia}

Najwyższą przeżywalność komórek mikroorganizmów uzyskuje się albo przy wolnym tempie ich chłodzenia wynoszącym $5 \div 180^{\circ} \mathrm{C} / \mathrm{min}$, albo przy bardzo szybkim - w zakresie $5000 \div 30000{ }^{\circ} \mathrm{C} / \mathrm{min}$. Chłodzenie komórek z szybkością pośrednią 180 $\div 5000{ }^{\circ} \mathrm{C} /$ min wiąże się $\mathrm{z}$ niską przeżywalnością mikroorganizmów. Optymalna szybkość chłodzenia zależy od zawartości wody w komórce, wielkości komórki, a także charakterystycznych właściwości danego mikroorganizmu. Im większa jest zawartość wody w komórce oraz im mniejszy jest rozmiar komórki (większy stosunek powierzchni do objętości) tym większa jest przeżywalność komórek podczas powolnego zamrażania $[12,13]$.

W praktyce w kolekcjach stosuje się wolne tempo chłodzenia i standardowo wynosi ono $1 \div 10^{\circ} \mathrm{C} / \mathrm{min}[2,3]$. W celu zapewnienia stałej szybkości chłodzenia niezbędne jest stosowanie urządzeń sterowanych elektronicznie, pozwalających na pełną kontrolę tego parametru. $\mathrm{Z}$ uwagi na wysokie koszty urządzenia te są stosowane tylko do zamrażania najbardziej wrażliwych szczepów. Prostszym rozwiązaniem są izolowane pojemniki (np. CollCell) zapewniające tempo chłodzenia $1^{\circ} \mathrm{C} / \mathrm{min}[2,3]$.

W literaturze dostępne są informacje o optymalnych szybkościach chłodzenia wybranych mikroorganizmów stosowanych na skalę przemysłową lub o dużym potencjale aplikacyjnym. Przykładowo w przypadku szczepu Lactobacillus coryniformis $\mathrm{Si} 3$ (biokonserwant) jest to $2,8^{\circ} \mathrm{C} / \mathrm{min}$ [28], a Lactobacillus casei ATCC 393 (probiotyk) $5^{\circ} \mathrm{C} /$ min [11]. Natomiast w badaniach Wanga i wsp. [37] największą przeżywalność Lactobacillus plantarum uzyskano przy szybkości chłodzenia wynoszącej $10{ }^{\circ} \mathrm{C} / \mathrm{min}$, a Lactobacillus casei $-1{ }^{\circ} \mathrm{C} / \mathrm{min}$.

\section{Faza wzrostu i liczba komórek w zawiesinie}

Na przeżywalność mikroorganizmów podczas procesu zamrażania ma także wpływ faza ich wzrostu oraz liczba w zamrażanej zawiesinie. Największą przeżywalnością cechują się mikroorganizmy pochodzące z późnej fazy logarytmicznej lub wczesnej stacjonarnej $[16,32]$. Liczba komórek bakterii i drożdży powinna wynosić co najmniej $10^{8} \mathrm{jtk} / \mathrm{ml}$ zawiesiny [16]. W przypadku grzybów strzępkowych zalecana liczba to co najmniej $10^{6}$ zarodników/ml $[3,4]$.

\section{Rozmrażanie}

Proces rozmrażania komórek jest jeszcze bardziej znaczący niż zamrażanie [23]. Wiele czynników, takich jak szok temperaturowy, toksyczność krioprotektantów, stres 
oksydacyjny oraz uszkodzenia komórki podczas rozmrażania może powodować zmiany w genotypie i fenotypie mikroorganizmu [15]. W czasie rozmrażania komórka ulega rehydratacji, uzyskuje właściwy kształt oraz skład płynu komórkowego. Ponadto usuwa ze swojego wnętrza substancję ochronną. Proces rozmrażania powinien odbywać się na tyle szybko, by nie doszło do uszkodzeń struktur komórkowych. Ponadto musi trwać odpowiednio długo, by komórka uzyskała stan równowagi osmotycznej [23]. W praktyce w kolekcjach stosuje się rozmrażanie komórek bakterii w łaźni wodnej o temp. $37{ }^{\circ} \mathrm{C}$ (lub innej optymalnej dla danego szczepu bakterii), delikatnie mieszając przez 2 min [2]. Komórki drożdży i grzybów strzępkowych rozmraża się w łaźni wodnej o temp. $25 \div 30^{\circ} \mathrm{C}$ (lub innej optymalnej dla danego szczepu), również mieszając przez $5 \min [3]$.

\section{Liofilizacja (suszenie sublimacyjne)}

Liofilizacja jest procesem polegającym na usunięciu wody z uprzednio zamrożonych substancji. Technika ta pozwala na przygotowanie wysuszonego preparatu mikroorganizmów, który może zostać łatwo ożywiony przez nawodnienie [40]. Proces liofilizacji jest złożony i przebiega w kilku etapach: zamrażanie, suszenie pierwotne i suszenie wtórne. Do zamrażania preparatów stosuje się zwykle ciekły azot lub mieszaniny chłodzące (np. suchy lód $\mathrm{z}$ etanolem). Suszenie odbywa się w warunkach próżniowych [20]. Gdy ciśnienie zostaje zmniejszone, a temperatura wzrośnie, rozpoczyna się sublimacja kryształów lodu utworzonych w komórce podczas zamrażania, tj. bezpośrednie przejście lodu w stan gazowy. Woda, która nie uległa wcześniej zamrożeniu jest desorbowana $\mathrm{z}$ liofilizatu w etapie suszenia wtórnego. Końcowa zawartość wody w liofilizacie uzależniona jest m.in. od temperatury, ciśnienia i czasu prowadzenia procesu suszenia, rodzaju substancji ochronnej, a także szczepu mikroorganizmu. Zawartość wody w wysuszonym preparacie wynosi $2 \div 6 \%$ [26]. Zaleca się przechowywanie liofilizatów bez dostępu światła, w pomieszczeniach o temp. $5 \div 15{ }^{\circ} \mathrm{C}$ [16]. Metoda ta jest niestety czasochłonna i dość kosztowna, ponieważ wymaga zaawansowanego sprzętu oraz znacznych ilości energii [24].

\section{Czynniki wpływające na skuteczność procesu liofilizacji}

Przeżywalność komórek mikroorganizmów poddawanych procesom liofilizacji jest wypadkową wielu czynników. Są to m.in. liczba komórek w zawiesinie wyjściowej, rodzaj i stężenie substancji ochronnej a także warunki rehydratacji i ożywienia mikroorganizmu. Substancje ochronne stosowane w procesach liofilizacji muszą zapewnić ochronę komórek zarówno na etapie zamrażania, jak i suszenia. W kolekcjach jako substancje ochronne stosowane są głównie: odtłuszczone mleko, mleko z dodatkiem trehalozy i glutaminianu sodu, mieszanina bulionu tryptonowo-sojowego, sacharozy i albuminy surowicy wołowej, mieszanina sacharozy i albuminy surowicy woło- 
wej, surowica końska z dodatkiem glukozy lub dodatek sacharozy do pożywki wzrostowej $[2,3,5,35]$.

Szczepy, których preparaty stosuje się przemysłowo, poddawane są kompleksowym badaniom zmierzającym do optymalizacji procesu utrwalania. $\mathrm{W}$ badaniach Costy i wsp. [8] dotyczących liofilizacji komórek Pantoea agglomerans CPA-2 (biologiczny środek ochrony roślin), najwyższą przeżywalność uzyskano, gdy liczba komórek w zawiesinie wyjściowej wynosiła $10^{10} \mathrm{jtk} / \mathrm{ml}$, substancję ochronną stanowiła 10-procentowa sacharoza, a jako pożywkę rehydratacyjną zastosowano 10-procentowe odtłuszczone mleko. Najwyższą przeżywalność komórek Pseudomonas chlororaphis (biologiczny środek ochrony roślin) po procesie liofilizacji uzyskano natomiast przy ich liczbie w przedziale $10^{9} \div 10^{10} \mathrm{jtk} / \mathrm{ml}$ zawiesiny wyjściowej, a 10-procentowy roztwór sacharozy stanowił substancję ochronną [25].

Podczas optymalizacji procesu liofilizacji komórek drożdży Metschnikowia pulcherrima (biologiczny środek ochrony roślin) wykazano, że najwyższą przeżywalność zapewniało zastosowanie zawiesiny o liczbie $10^{8} \mathrm{jtk} / \mathrm{ml}$, przygotowanej z 36-godzinnej hodowli, 25-procentowego roztworu maltozy jako środka ochronnego oraz zastosowanie do rehydratacji płynu Ringera [32].

W tab. 1. przedstawiono zalety i wady dwóch podstawowych metod stosowanych do utrwalania, a następnie długotrwałego przechowywania mikroorganizmów.

\section{Kontrola stabilności genotypowej i fenotypowej przechowywanych mikroorganizmów}

Zmiany genotypowe i fenotypowe mikroorganizmów przechowywanych w kolekcjach kultur mogą być indukowane przez takie czynniki, jak: szok temperaturowy, stres oksydacyjny, toksyczność krioprotektantów oraz tworzenie się lodu wewnątrzkomórkowego [27].

Istnieje kilka metod typowania molekularnego stosowanych do monitorowania zmian w materiale genetycznym bakterii i grzybów. Wyróżnia się wśród nich badanie polimorfizmu długości amplifikowanych fragmentów (ang. AFLP, Amplified Fragment Length Polymorphism), sekwencjonowanie genów metabolizmu podstawowego (ang. MLST, Multi-Locus Sequence Typing), elektroforezę żelową w polu pulsacyjnym (ang. PFGE, Pulsed Field Gel Electrophoresis), PCR w czasie rzeczywistym (ang. RealTime PCR, qPCR) oraz porównywanie całego genomu [27].

Przed udostępnieniem przez kolekcję kultur mikroorganizmów ośrodkom naukowym czy firmie produkcyjnej, konieczne jest ponowne sprawdzenie żywotności, aktywności, zdolności do wzrostu oraz czystości [31]. 
Tabela 1. Zalety i wady zamrażania i liofilizacji mikroorganizmów

Table 1. Advantages and disadvantages of freezing and freeze-drying of microorganisms

\begin{tabular}{|c|c|c|}
\hline $\begin{array}{c}\text { Metoda } \\
\text { utrwalania } \\
\text { Preservation } \\
\text { technique }\end{array}$ & $\begin{array}{c}\text { Zalety } \\
\text { Advantages }\end{array}$ & $\begin{array}{c}\text { Wady } \\
\text { Disadvantages }\end{array}$ \\
\hline $\begin{array}{l}\text { Zamrażanie } \\
\text { Freezing }\end{array}$ & $\begin{array}{l}\text { - Wysoka przeżywalność mikroorganizmów } \\
\text { przy zastosowaniu krioprotektantów / High } \\
\text { survival rate of microorganisms with the use } \\
\text { of cryoprotectants } \\
\text { - Metoda tania, łatwa do przeprowadzenia } \\
\text { Inexpensive, easy to conduct method } \\
\text { - Metoda odpowiednia dla większości } \\
\text { mikroorganizmów / Technique suitable for } \\
\text { most of microorganisms }\end{array}$ & $\begin{array}{l}\text { - Trudności w transporcie } \\
\text { zamrożonych preparatów } \\
\text { mikroorganizmów / Difficulties in } \\
\text { transporting frozen preparations of } \\
\text { microorganisms } \\
\text { - Wahania temperatury powodujące } \\
\text { utratę stabilności utrwalonych } \\
\text { mikroorganizmów / Temperature } \\
\text { fluctuations causing loss of } \\
\text { stability of preserved } \\
\text { microorganisms } \\
\text { - Potrzeba okresowego } \\
\text { uzupełniania azotu / The need for } \\
\text { periodic nitrogen replenishment } \\
\text { - Duże zużycie energii / High rate } \\
\text { of energy consumption }\end{array}$ \\
\hline $\begin{array}{l}\text { Liofilizacja } \\
\text { Freeze-drying }\end{array}$ & $\begin{array}{l}\text { - Wysoka przeżywalność mikroorganizmów } \\
\text { przy zastosowaniu substancji ochronnych } \\
\text { High survival rate of microorganisms when } \\
\text { using protective substances } \\
\text { - Metoda zapewniająca zachowanie cech } \\
\text { biochemicznych, morfologicznych } \\
\text { i immunologicznych komórek nawet po } \\
\text { długoletnim przechowywaniu / Technique } \\
\text { that ensures biochemical, morphological and } \\
\text { immunological features of cells are retained } \\
\text { even after long-term storage } \\
\text { - Metoda odpowiednia głównie dla } \\
\text { organizmów prokariotycznych / Technique } \\
\text { suitable mainly for prokaryotes } \\
\text { - Ochrona przed zakażeniami } \\
\text { i zanieczyszczeniami podczas } \\
\text { przechowywania / Protection against } \\
\text { infection and contamination during storage } \\
\text { - Stabilność utrwalonych preparatów } \\
\text { mikroorganizmów w temperaturze pokojowej } \\
\text { Stability of preserved preparations of } \\
\text { microorganisms at room temperature } \\
\text { - Łatwość dystrybucji / Easy distribution }\end{array}$ & $\begin{array}{l}\text { - Narażenie komórek na stres } \\
\text { spowodowany zmianą pH, niskimi } \\
\text { temperaturami, wysokim stężeniem } \\
\text { substancji rozpuszczonych, } \\
\text { tworzeniem kryształów lodu, } \\
\text { usuwaniem wody / Exposing cells } \\
\text { to stress caused by changes in pH, } \\
\text { low temperatures, high } \\
\text { concentration of solutes, formation } \\
\text { of ice crystals, removal of water } \\
\text { - Metoda czasochłonna / Time- } \\
\text { consuming technique } \\
\text { - Wysokie koszty stałe i operacyjne } \\
\text { High fixed and operating costs } \\
\text { - Skomplikowana procedura } \\
\text { wymagająca optymalizacji } \\
\text { warunków procesu / Complicated } \\
\text { procedure that requires } \\
\text { optimization of process conditions }\end{array}$ \\
\hline
\end{tabular}

Źródło / Source: opracowanie własne na podstawie $[15,16]$ / the author's own study based on $[15,16]$ 


\section{Podsumowanie}

Z powodu ogromnej różnorodności mikroorganizmów nie można wybrać jednej, odpowiedniej dla wszystkich techniki utrwalania i przechowywania [27], jednakże zamrażanie i liofilizacja pozostają od wielu lat uniwersalnymi metodami stosowanymi w tym celu.

Na skuteczność metod utrwalania mają wpływ: rodzaj, gatunek, a nawet szczep mikroorganizmu, rozmiar komórki, zawartość lipidów i wody w komórce, faza zbioru komórek, liczba komórek oraz skład medium do zawieszania mikroorganizmów przeznaczonych do utrwalenia, a następnie przechowywania. W przypadku zamrażania istotne są również temperatura, czas i szybkość prowadzenia tego procesu oraz dodatek krioprotektantów. Na żywotność mikroorganizmów po rozmrożeniu bądź nawodnieniu (liofilizaty) mają również wpływ temperatura, czas i szybkość prowadzenia procesu.

\section{Literatura}

[1] Abadias M., Benabarre A., Teixido N., Usall J., Vinas I.: Effect of freeze drying and protectants on viability of the biocontrol yeast Candida sake. Int. J. Food Microbiol., 2001, 65 (3), 173-182.

[2] ATCC: Bacterial Culture Guide. [on line]. Dostęp w Internecie [07.02.2021]: https://www.lgcstandards-atcc.org/ /media/PDFs/Culture\%20Guides/ATCC_Bacterial_Culture_ Guide.ashx

[3] ATCC: Mycology Culture Guide. [on line]. Dostęp w Internecie [07.02.2021]: https://www.lgcstandards-atcc.org/ /media/PDFs/Culture\%20Guides/Mycology_Guide.ashx

[4] ATTC: Preservation and Recovery of Filamentous Fungi. [on line]. Dostęp w Internecie [07.02.2021]: https://www.atcc.org/ /media/PDFs/Technical\%20Bulletins/ tb02.ashx

[5] Bond C.: Freeze-drying of yeast cultures. In: Cryopreservation and Freeze-Drying Protocols. $2^{\text {nd }}$ ed. Eds. J.G. Day, G.N. Stacey. Humana Press Inc., Totowa, New Jersey, 2007, pp. 99-108.

[6] Breierová E., Kocková-Kratochvilová A.: Cryoprotective effects of yeast extracellular polysaccharides and glycoproteins. Cryobiology, 1992, 29 (3), 385-390.

[7] Calcott P.H.: Cryopreservation of microorganisms. Crit. Rev. Biotechnol., 1986, 4 (3), 279-297.

[8] Costa E., Usall J., Teixidó N., Garcia N., Viñas I.: Effect of protective agents, rehydration media and initial cell concentration on viability of Pantoea agglomerans strain CPA-2 subjected to freezedrying. J. Appl. Microbiol., 2000, 89 (5), 793-800.

[9] Cota A.L.S., Alvim R.G.: Effect of storage temperature on Streptococcus mutans viability. Rev. Odontol. UNESP, 2018, 47 (2), 74-78.

[10] Criste A., Giuburuncă M., Negrea O., Dan S., Zăhan M.: Research concerning use of long-term preservation techniques for microorganisms. J. Anim. Sci., 2014, 47 (2), 73-77.

[11] Dimitrellou D., Kandylis P., Kourkoutas Y.: Effect of cooling rate, freeze-drying, and storage on survival of free and immobilized Lactobacillus casei ATCC 393. LWT, 2016, 69, 468-473.

[12] Dumont F., Marechal P.A., Gervais P.: Influence of cooling rate on Saccharomyces cerevisiae destruction during freezing: Unexpected viability at ultra-rapid cooling rates. Cryobiology, 2003, 46 (1), 33-42.

[13] Dumont F., Marechal P.A., Gervais P.: Cell size and water permeability as determining factors for cell viability after freezing at different cooling rates. Appl. Environ. Microbiol., 2004, 70 (1), 268272. 
[14] Fonseca F., Beal C., Mihoub F., Marin M., Corrieu G.: Improvement of cryopreservation of Lactobacillus delbrueckii subsp. bulgaricus CFL1 with additives displaying different protective effects. Int. Dairy J., 2003, 13 (11), 917-926.

[15] Guo N., Wei Q., Xu Y.: Optimization of cryopreservation of pathogenic microbial strains. J. Biosaf. Biosecur., 2020, 2 (2), 66-70.

[16] Heylen K., Hoefman S., Vekeman B., Peiren J., de Vos P.: Safeguarding bacterial resources promotes biotechnological innovation. Appl. Microbiol. Biotechnol., 2012, 94 (3), 565-574.

[17] Hubálek Z.: Protectants used in the cryopreservation of microorganisms. Crybiology, 2003, 46 (3), 205-229.

[18] Hubálek Z., Kocková-Kratochvílová A.: Long-term preservation of yeast cultures in liquid nitrogen. Folia Microbiol. (Praha), 1982, 27 (4), 242-244.

[19] Jang T.H., Park S.C., Yang J.H., Kim J.Y., Seok J.H., Park U.S., Choi C.W., Lee S.R., Han J.: Cryopreservation and its clinical applications. Integr. Med. Res., 2017, 6 (1), 12-18.

[20] Kamboj N., Maurya S., Kamboj S., Singh G.K.: Lyophilisation process - an overview. [on line]. PharmaTutor, 2013. Dostęp w Internecie [15.04.2020]: https:/www.pharmatutor.org/ articles/lyophilization-process-overview

[21] Misiewicz A., Suchorzyńska M., Kieliszek M., Goncarzewicz A.: Zasady przyjmowania i przechowywania drobnoustrojów w kolekcji. W: Kolekcja kultur drobnoustrojów przemysłowych. Red. A. Misiewicz. IBPRS, Warszawa 2009, ss. 35-47.

[22] Morris G.J.: Cryopreservation: An introduction to cryopreservation in culture collections. Institute of Terrestrial Ecology, Cambridge 1981, pp. 5-14.

[23] Niwińska A.: Przegląd metod kriokonserwacji pod kątem techniki witryfikacyjnej. Życie Weter., 2016, 91 (7), 505-508.

[24] Nyanga L.K., Nout M.J.R., Smid E.J., Boekhout T., Zwietering M.H.: Yeasts preservation: Alternatives for lyophilisation. World J. Microbiol. Biotechnol., 2012, 28 (11), 3239-3244.

[25] Palmfeldt J., Rådström P., Hahn-Hägerdal B.: Optimisation of initial cell concentration enhances freeze-drying tolerance of Pseudomonas chlororaphis. Cryobiology, 2003, 47 (1), 21-29.

[26] Peiren J., Buyse J., De Vos P., Lang E., Clermont D., Hamon S., Bégaud E., Bizet C., Pascual J., Ruvira M.A., Macián M.C., Arahal D.R.: Improving survival and storage stability of bacteria recalcitrant to freeze-drying: A coordinated study by European culture collections. Appl. Microbiol. Biotechnol., 2015, 99 (8), 3559-3571.

[27] Prakash O., Nimonkar Y., Shouche Y.S.: Practice and prospects of microbial preservation. FEMS Microbiol. Lett., 2013, 339 (1), 1-9.

[28] Schoug A., Olsson J., Carlfors J., Schnürer J., Håkansson S.: Freeze-drying of Lactobacillus coryniformis Si3-effects of sucrose concentration, cell density, and freezing rate on cell survival and thermophysical properties. Cryobiology, 2006, 53 (1), 119-127.

[29] Singh S.K., Baghela A.: Cryopreservation of microorganisms. In: Modern Tools and Techniques to Understand Microbes. Eds. A. Varma, A.K. Sharma. Springer International Publishing, Cham, Szwajcaria, 2017, pp. 321-333.

[30] Smith D., Ryan M.: Implementing best practices and validation of cryopreservation techniques for microorganisms. Sci. World J., 2012, 2012, 1-9.

[31] Smith D.: Culturing, preservation and maintenance of fungi. In: Plant Pathologist's Pocketbook. $3^{\text {rd }}$ ed. Eds. J.M. Waller, J.M. Lenné, S.J. Walker. CAB International, Wallingford, UK, 2002, pp. 384409.

[32] Spadaro D., Ciavorella A.A., Lopez-Reyes J.G., Garibaldi A., Gullino M.L.: Effect of culture age, protectants, and initial cell concentration on viability of freeze-dried cells of Metschnikowia pulcherrima. Can. J. Microbiol., 2010, 56 (10), 809-815. 
[33] Stefanello R.F., Nabeshima E.H., Iamanaka B.T., Ludwig A., Fries L.L.M., Bernardi A.O., Copetti M.V.: Survival and stability of Lactobacillus fermentum and Wickerhamomyces anomalus strains upon lyophilisation with different cryoprotectant agents. Food Res. Int., 2019, 115, 90-94.

[34] Tedeschi R., De Paoli P.: Collection and preservation of frozen microorganisms. In: Methods in Biobanking. Ed. J. Dillner. Humana Press, Totowa, New Jersey, 2010, 313-326.

[35] Tindall B.J.: Vacuum-drying and cryopreservation of prokaryotes. In: Cryopreservation and FreezeDrying Protocols. $2^{\text {nd }}$ ed. Eds. J.G. Day, G.N. Stacey. Humana Press Inc., Totowa, New Jersey, 2007, pp. 73-98.

[36] Tymczyszyn E.E., Díaz R., Pataro A., Sandonato N., Gómez-Zavaglia A., Disalvo A.: Critical water activity for the preservation of Lactobacillus bulgaricus by vacuum drying. Int. J. Food Microbiol., 2008, 128 (2), 342-347.

[37] Wang G., Yu X., Lu Z., Yang Y., Xia Y., Lai P.F.-H., Ai L.: Optimal combination of multiple cryoprotectants and freezing-thawing conditions for high lactobacilli survival rate during freezing and frozen storage. LWT, 2019, 99, 217-223.

[38] Webb K.M., Holman G., Duke S., Greene S., McCluskey K.: Frozen fungi: Cryogenic storage is an effective method to store Fusarium cultures for the long-term. Ann. Appl. Biol., 2018, 173, 133-140.

[39] Yalcin-Duygu D., Erdem B., Ozer T., Acikgoz-Erkaya I.: Long-term storage of a number of microorganism species using different cryoprotectants. Fresenius Environ. Bull., 2018, 27 (6), 4318-4324.

[40] Zhai S., Taylor R., Sanches R., Slater N.K.H.: Measurement of lyophilisation primary drying rates by freeze-drying microscopy. Chem. Eng. Sci., 2003, 58 (11), 2313-2323.

\section{FREEZING AND FREEZE-DRYING AS TECHNIQUES OF PRESERVING AND STORING MICROORGANISMS}

\section{S u m m a ry}

The task of culture collections is to collect and store microorganisms in order to protect the biodiversity of biological resources. Culture collections function as strain repositories for the purpose of scientific research, teaching, industrial applications and patent deposits. Also, in the culture collections of microorganisms, research is conducted to identify, characterise, classify and improve functional properties of the resources stored. During storage it is important to keep the morphology, enzymatic activity and genetic material of those microorganisms unaltered and to ensure their high survival rate. For safety reasons and to minimise the risk of losing strains, it is recommended by the World Federation for Culture Collection (WFFCC) to use at least two various procedures for storing them.

In the paper there are presented freezing and freeze-drying as techniques of preserving and storing microorganisms most frequently applied in collections. The article may be useful when selecting a suitable preservation technique, process and storage conditions, and an appropriate technique to revive the preserved microorganisms.

Key words: techniques of preserving and storing microorganisms, freezing, freeze-drying, cryoprotectants 承 